Marquette University

e-Publications@Marquette

5-1-2014

\title{
The Irish Protestant Imaginary: The Cultural Contexts for the Gothic Chapbooks Published by Bennett Dugdale, 1800-1805
}

Diane Hoeveler

Marquette University, diane.hoeveler@marquette.edu

Accepted version. "The Irish Protestant Imaginary: The Cultural Contexts for the Gothic Chapbooks Published by Bennett Dugdale, 1800-1805," in Irish Gothics: Genres, Forms, Modes, and Traditions, 1760-1890. Eds. Christina Morin and Niall Gillespie. New York: Palgrave-Macmillan, 2014. DOI. (C) 2014 Palgrave-Macmillan. Used with permission.

This extract is taken from the author's original manuscript and has not been edited. The definitive, published, version of record is available here: http://us.macmillan.com/irishgothics/

ChristinaMorin\#toc 


\section{The Irish Protestant Imaginary: The Cultural Contexts for the Gothic Chapbooks Published by Bennett Dugdale, 1800-1805}

\section{Diane Long Hoeveler}

What vanity and presumption! that man should suppose he can pardon the sins of others, and yet have the weight of so many on his own head! Why did he not stay in the land of superstition?-I should blush at seeing an Englishman on his knees to you,- - more than I should at hearing a long catalogue of transgressions. It is more excusable to fall down before a crucifix - it might convey to the mind an idea of a great transaction.- But to kneel to such a man as that, is to pay adoration to the representative of folly and inconsistency—for the Romish priest is no better than his neighbours. - May the supplications of mankind be ever and only addressed to that Being who is placed far above all principality and power,- - and might,dominion — and every name that is named, not only in this world, but that which is to come. ${ }^{1}$

\section{The Historical Context}

Perhaps it is just a coincidence, but when the former Catholic priest Antonio Gavin (1680-?) decided to flee Spain he headed first to London and then finally to Ireland, where the Dublin publisher George Grierson produced his diatribe against the Catholic Church, The Great Red Dragon; or The Master-key to Popery (1724). Twenty years later an anonymous and mean- 
spirited satire on Catholic doctrines was published by James Carson in Dublin: Purgatory Prov'd: Illustrated and set forth, in a clear Light. By Father Murtagh O'Lavery. Priest of the Parish of St. John's Dromore, and Macherlin. In a Funeral Sermon, upon the death of one of his parishioners (1746). Using an exaggerated Irish dialect that mocks the lower-class origins of the priest, the anonymous satirist has Fr. O'Lavery refer to Purgatory as 'de Turd Plath' (6). And then in 1773 Elizabeth Bonhôte (1744-1818), first published her vindictive attack on Catholic priests in The Rambles of Mr. Frankly, Published by His Sister in Dublin with Messrs. Sleater, Lynch, Williams, Potts, Chamberlaine, excerpted in the epigram above. There is also a very early gothic monk villain in Longsword, Earl of Salisbury (1762), written by the Anglo-Irish clergyman and historian Thomas Leland and published in its first Dublin edition by George Faulkner (1762). Generally discussed as a pre-gothic novel in the Loyalist tradition, ${ }^{2}$ this historical romance features an evil monk named Brother Reginald who domineers over the local monastery where the besieged heroine Ela's son has been sent by the usurping villain Raymond (much of this plot would be repeated later in slightly altered form in Matthew Lewis's popular gothic drama The Castle Spectre, 1797). Reginald is such an odious character that Tarr observes, 'it is significant that Reginald's conduct is exceptional and that ... his brothers detest him and try to control his excesses' ${ }^{3}$ Matthew Lewis's anti-Catholic tome, The Monk, was published in Dublin for the first time in 1796 by P. Wogan (and then reprinted by various houses in 1797 and 1808), while The Adventures of Signor Gaudentio di Lucca, a sensationalistic Inquisition trial account, was published in Dublin by J. Carrick in 1798. The Dublin publisher Arthur O'Neil produced the anonymous and blatantly anti-Catholic chapbook Mystery of the Black Convent, based on The Monk in $1814 .{ }^{4}$ Finally, one could mention the Dublin-born Anglican minister 
Charles Maturin, descended from Huguenots, who published his Five Sermons on the Errors of the Roman Catholic Church in Dublin with William Curry in 1824.

My point in listing these examples of only a few of the hundreds of anti-Catholic texts that appeared in Ireland during this period is to suggest that there were a number of publishers in Dublin who were interested in and committed to publishing some of the most extreme antiCatholic propaganda being written during the eighteenth and nineteenth centuries. ${ }^{5}$ And while we may now think of Ireland, and in particular Dublin, as a dominant Catholic culture, we would be mistaken to assume that such was the case for the eighteenth century. At that time a minority Anglo-Irish ascendancy dominated the religious, social, and political life of Ireland, while the majority Roman Catholic population struggled to maintain a cultural presence in proportion to their numbers. Certainly there were Irish Catholic publishers producing Catholic religious works, ${ }^{6}$ and there was a strong nationwide Catholic Committee campaign as early as 1792 which published widely, as historians like Kelly, Whelan, and Bartlett have noted. ${ }^{7}$ Men like Hugh Fitzpatrick, John Coyne, and Richard Coyne were active in publishing Catholic texts, but each one of them was supported at one point or another by 'ecclesiastical authority'. ${ }^{8}$ Apart from these early efforts, however, more aggressive and propagandistic responses by Catholic publishers did not become overtly antagonistic until 1823, when W. J. Battersby started his own press specifically designed to counter the productions of Protestant publishing houses. In 1825 he wrote to a friend, 'I agree with you that the Biblicals are industrious in disseminating their pestiferous tracts and the Catholics are grossly negligent in counteracting their efforts. I have at my own personal risk published the works you see marked in the catalogue'. ${ }^{9}$ One of those 'Biblicals', I would contend, was Bennett Dugdale, Methodist publisher. 
It is not, I think, unfair to state, as Foster has, ${ }^{10}$ that the Irish Protestant imaginary was well aware of its own acts of usurpation and that this violation of a land and its indigenous heritage found literary expression in the sense of being haunted by a repressed and threatening Catholic majority population. But another explanation is possible as well. Memories of Catholic atrocities committed against Protestants in Ulster and beyond were continually revived in the Protestant Imaginary, Richard Musgrave's (1746-1818) Memoirs of the Different Rebellions in Ireland (1801) being just one recent example. Musgrave's text was a pro-loyalist history that linked the failed Irish rising of 1798 to a longer and more complicated tale of Catholic crimes against Protestants. ${ }^{11}$ Hence what I am calling the 'Irish Protestant Imaginary' manifests itself as what we would recognize as textual displays of anti-Catholicism, and is composed of equal parts of guilt, anxiety, fear, and disdain for the native religion of the majority population. ${ }^{12}$

It is revealing that defenses of Catholicism tended to be published in places like Cork, for instance, by the Cork publisher John Connor who published in 1813 Plain Facts, by Eneas MacDonnell, a defense of Catholics in the face of Protestant agitation against the Catholic Emancipation bill. Connor was, according to Loeber and Loeber, 'the single most important publisher in Ireland of original fiction at the time when reprints of English authors prevailed' ${ }^{13}$ The full title reveals the pamphlet's position: Plain Facts, demonstrating The Injustice and Inconsistency of Anti-Catholic Hostility, fairly illustrated in a letter to the Rev. J. Coates, Vicar, Chairman of the Meeting of Clergy, Gentry, and Inhabitants of Huddersfield and Vicinity, who have resolved to petition Parliament against the Roman Catholic Claims (original pamphlet in Cambridge University Library). Clearly, Catholics were on the defensive. The fact was that until the 1778 and 1782 Relief Acts they could not own property, vote, or work for the 
government except as cannon fodder. And then during this decade the gothic novel became all the rage in England, France, and Germany.

The anti-Catholic tone of the majority of gothic works in the European imaginary has been extensively documented and explored in a number of scholarly studies published during the past thirty years. ${ }^{14}$ And scholars of the Irish literary tradition have certainly noticed the trend as well. ${ }^{15}$ This article will focus on a question that has not to my knowledge been explored: what can we learn about specific Dublin publishers by looking at the titles they chose to publish as revealing the ideological content of their catalogues? In short, were publishers who produced gothic materials operating according to purely financial motivations as has usually been asserted ${ }^{16}$ or did they have an ideological (political and religious) agenda in their choice of works to reprint from London? Although we know a few tantalizing facts about only a handful of these men working in Dublin and Cork, we do have catalogues of their published works to guide us in making some judgments about their intentions, and, by extension, about the characteristics of the book-trade in Ireland at this time. Using a sampling of the gothic chapbooks published by the Dublin Methodist Bennett Dugdale (1771-1826), ${ }^{17}$ this article will examine the larger historical and cultural contexts associated with four of the nineteen titles in his catalogue of published chapbooks: Father Innocent, Phantasmagoria, Amalgro \& Claude, and The Secret Tribunal, all of them anti-Catholic gothic chapbooks that he issued in collaboration with the London-based publishing house of Tegg and Castleman under the direction of Thomas Tegg. Although Loeber and Loeber discuss this collaboration and have documented that nineteen chapbooks originally published in London by Tegg were produced in collaboration with Dugdale, they have not been able to prove that the chapbooks were exported to Dublin for circulation. ${ }^{18}$ I would state here that, given what we know of Dugdale's religious 
sympathies, that is, that he blocked the sale of a Methodist chapel to Jesuits and his biographer labeled him as 'bigoted', ${ }^{19}$ it is difficult not to believe that these particular chapbooks were very specifically selected for their anti-Catholic contents and that they were intended for a Methodist and Church of Ireland readership keen to have their prejudices and fears about Roman Catholicism confirmed. I make this assertion (rather boldly) because Tegg himself had a history of publishing anti-Catholic chapbooks and, in fact, he had gone so far as to appropriate the identity of a notorious Irishman, George Barrington, in order to claim that Barrington was the author of an anti-Catholic chapbook that Tegg himself published in London in $1803{ }^{20}$ If the chapbooks were not intended for circulation in Ireland, why was Dugdale involved in their production?

By way of additional historical background, it is important to note that in 1793 the Irish Parliament, at the direction of Pitt's government, passed a Relief Act that gave Irish Catholics the right to vote. The earlier Reliefs Acts of 1778 and 1782 allowed Catholics the right to own property, as long as such property did not automatically confer on the proprietor the right to select a member of Parliament. And in 1801 the Anglo-Irish Union established formal governmental ties between England and Ireland, thereby adding some three and a half million Irish Roman Catholics to the population of the United Kingdom (raising their numbers to thirty percent). Traditionally, the Act of Union that went into effect on January 1, 1801, has been seen as having a devastating effect on publishing in Ireland because it extended English copyright law to Ireland, thereby curtailing the ability of Irish publishers to pirate English books. ${ }^{21}$ Although Maureen Wall and others have claimed that the atmosphere in Dublin was increasingly less antiCatholic as their numbers grew in the city after the Act of Union, the publishing climate was another matter. $^{22}$ Between 1801 and 1823, there were a number of Dublin publishers producing 
anti-Catholic propaganda and the gothic's popularity gave Protestant publishers like Dugdale an opening: they could propagandize against Catholicism at the same time they entertained and titillated the lower and middling classes with their profitable anti-Catholic gothic chapbooks. After 1823 there was an Irish Catholic Association, led by Daniel O'Connell, working in concert with the priests of Ireland in order to influence local elections of Members of Parliament and to call up public demonstrations of 5,000 men in a very short order. ${ }^{23}$ O'Connell's election to Parliament for County Clare in 1828 is generally recognized as the tipping point in putting pressure on the Wellington Tory administration to finally pass the Emancipation Act in 1829, but clearly the way had been paved by recognizing the constant need of the British government for Irish Catholic soldiers to shore up its far-flung imperialistic ventures in the British colonies of America, Canada, and India.

Throughout the sixteenth and seventeenth centuries, tales of Popish atrocities focused on the Marian persecutions and evolved into folklorish witch tales about 'Bloody Mary' Tudor. 'Bloody' was a word routinely associated with the religion, ${ }^{24}$ no doubt recalling the reign of Mary Tudor, as well as the St. Bartholomew's eve massacre in France in 1572, the Irish 'massacres' of 1641, and the Great Fire of London in 1666, laid at the feet of Catholics. In fact, as late as 1830, the Monument to the London fire carried an inscription stating that it had been started by 'the treachery and malice of the popish faction'. As Linda Colley has noted, 'outlandish' was another word that was frequently attached to Catholics because they were 'out of bounds, did not belong, were suspect'. The religion was linked to Rome, France, and Spain, England's traditional enemies and potential invaders. Colley also observes that during the Gordon Riots Catholics were frequently dunked in rivers exactly the way that reputed witches had been: 'in times of danger or insecurity, Catholics - like witches — became scapegoats, easy 
targets on which their neighbours could vent fear and anger'. 'Swimming' people suspected of witchcraft occurred in Suffolk as late as $1795,{ }^{26}$ so clearly the belief in the power of witches and other manifestations of 'magical' beliefs was rife in popular, lower-class consciousness during the height of the gothic ideology. From viewing Catholics as witches who need to be confronted and destroyed, it was but a short step to understanding the popularity of gothic works that prominently feature witches, like George Walker's The Three Spaniards (1800), James Norris Brewer's The Witch of Ravensworth (1808), and Quintin Poynet's The Wizard Priest and the Witch (1822), just to name a few. And it is certainly instructive that the origin of the word 'coven' is the same as for 'convent'. 27

Clearly, if there was a historical residue that haunted the conscious and unconscious British psyche, it was the spectre of Roman Catholicism, in all its garish, violent, corrupt, and nostalgic splendors. And so it is not difficult to see the emergence of the gothic as a form of remediation, a textual reinterpretation of Britain's historical past, as a literary response or what we might recognize as an imaginative engagement with an ambivalent history that all classes had a difficult time understanding or intellectually processing. Hence the events of the recent and more distant past become so much representative fodder for the public imagination to turn around in its hands so to speak, bring its materials into the glare of the light, look at from different directions and perspectives in order to more fully comprehend and thereby control and contain.

Another way of approaching this question is to note that at the same time a lower-class imaginary was emerging in Great Britain, a nationalistic and politicized form of Protestantism was institutionalizing itself and infiltrating the newly developing public sphere through the proliferation of a number of Protestant societies, all of which sponsored their own publication 
houses. For instance, the Society for the Preservation of Christian Knowledge (founded in 1699) printed a number of 'anti-Catholic chapbooks' for the lower classes, as well as A Protestant Catechism: Shewing the Principal Errors of the Church of Rome (1766), 24 pages, and written at the level of a child's understanding in a question and answer format. ${ }^{28}$ The SPCK kept up its publications for more than 200 years, often serving as the front line in its war on Roman Catholicism and that continues to fight even today in the work of someone like Ian Paisley. For more sophisticated readers there was the work of John White, who originally produced the very long anti-Catholic work The Protestant Englishman Guarded against the Arts and Arguments of Romish Priests and Emissaries (1753). But faced with the need to reach the masses with these warnings, the book was reissued in 1755 as A New Preservative against Popery, much abbreviated in size and cost, simpler content, and intended for dispersal 'among the lower People'. ${ }^{29}$ This virulently nationalistic form of Protestantism served as one of the primary unifying and identificatory totems around which the modern nation state of 'Great Britain' organized its sense of itself as an isolated island besieged on all sides by the forces of reactionary Catholicism.

William III's Popery Act of 1698 (passed by Parliament in 1700), made worship in a Roman Catholic Church illegal, while the penalty for a priest saying mass was perpetual imprisonment. The Act effectively placed a bounty on every priest's head, promising 100 pounds to anyone who could capture a 'Popish Bishop, Priest or Jesuite' who had said 'Mass or exercised any other Part of the Office or Function of a Popish Bishop or Priest within these Realmes'. ${ }^{30}$ Conversion to Popery became an offence, as did the sending of children abroad to Catholic countries for their educations. Further, under this Act Catholics at the age of eighteen were required to take the oaths of allegiance and supremacy and to renounce distinctively 
Catholic doctrines, most importantly Transubstantiation. If they refused, their estates were to be inherited by their next Protestant relatives. As Haydon has noted, had this requirement been rigorously enforced, 'Catholic landholding, and consequently seigniorial Catholicism, would soon have been a thing of the past; but various legal subterfuges had been found to evade the clause'. ${ }^{31}$

Within this extremely tense religious atmosphere, the flames of prejudice were fanned by what Habermas has labeled the newly developed bourgeois public sphere. For instance, by 1770 there were several religious debating societies which 'appear to have helped in communicating hatred of Catholicism to the lower orders, even bridging the gap between the literate and the illiterate', ${ }^{32}$ while Methodists took a large part 'in perpetuating anti-Popish prejudice in the latter half of the century'. ${ }^{33}$ The notorious anti-Catholic informer, William Payne, had Methodist connections, and John Wesley was involved in attacks on Popery and in the agitation that followed the passage of the first Catholic Relief Act (1778). In fact, the caption on a print circulated after the Gordon Riots presented Wesley as a reactionary fanatic: 'Religious strife is raisd to Life, / By canting whining John; / No Popery he loud doth cry, / To the deluded throng'. ${ }^{34}$ As Rudé has noted, the Gordon Riots 'drew on a long radical-Protestant tradition and were inspired (if not promoted) by the most radical elements in the city', men like the Baptist alderman Frederick Bull, a close friend and ally of Lord George Gordon in the anti-Papist cause. $^{35}$ More moderate Anglican clergymen feared this sort of religious extremism, knowing it could alarm the populace and lead to the sort of civil disturbances that wracked England during the Tudor dynastic struggles. This new tolerance toward Catholics seems to reveal what historians claim was a softening in attitudes towards them after large numbers of Scottish and Irish Catholics served with distinction during the Seven Years War and in India and the West 
Indies. ${ }^{36}$ While there was a growing spirit of tolerance during George III and George IV's reigns leading to the eventual passage of the Catholic Emancipation Act in 1829, there is no denying the fact of the Gordon Riots in London in 1780, nor the continued whipping-up of fear and anxiety toward Catholics as 'Others' that appears almost unabated in gothically-inflected texts throughout the nineteenth century. ${ }^{37}$ Even though there were no riots on the scale of what happened in 1780 , there was an anti-Catholic rally attended by 60,000 people in Kent after the passage of the 1829 Act: 'such protests-which were a nationwide phenomenon and have never been properly investigated — confirm yet again just how important Protestantism was in shaping the way that ordinary Britons viewed and made sense of the land they lived in'. ${ }^{38}$

In the midst of these religious disputes, as well as heated political, military, and economic debates about the status of religion in the national character, the ghost of Roman Catholicism continued to haunt the British Protestant imaginary. We can see manifestations of this ghostly presence writ large in the hundreds of gothic chapbooks and novels that seized the imaginations of the lower and middle-class Briton, while the longer and more expensive three-volume novels written by Ann Radcliffe, Matthew Lewis, Charles Maturin, William Henry Ireland, Edward Montague, and Thomas Isaac Curties Horsley peddled very much the same representations and scenarios for a more well-heeled reading population. In fact, it can be argued that the Whig ascendancy self-consciously employed the gothic in its campaign to demonize and scapegoat Catholics in the public consciousness. Relying on by now stereotyped tropes that had circulated for more than two hundred years in anti-Catholic propaganda and pornography-like the tyrannical and hypocritical Inquisitor, the lecherous monk or the lesbian nun-anti-Catholic gothics enlisted the familiar conventions from a variety of discourse systems intended for the lower- and middling classes. ${ }^{39}$ As Robert Darnton has observed, while the sophisticated and 
ironic classic of anti-clerical pornography Thérèse Philosophe (1748) may have been read primarily by the elite 'Champagne-and-oyster' crowd, ${ }^{40}$ its source materials were distilled into cheap, wordless chapbooks that circulated to the lowest level of readership, the poor and illiterate, in order to spread the same tale of clerical seduction. ${ }^{41}$ Relying on the fact that all levels of reading audiences would have been familiar with the staples of the anti-Catholic agenda, the gothic novelist could use them almost as shorthand for conveying in a few dramatic strokes all that threatened the beleaguered British Protestant nation. By the late eighteenth century through to 1829 , Britons were looking for a scapegoat and one came ready-made and uncannily familiar in the figure of the Catholic.

In an era that was characterized by the production of pornographic mockery, biting satire, and worse, anti-Catholic texts proliferated and invaded the British Protestant consciousness at all class levels. One of the most virulent and influential texts as I mentioned earlier was written by the apostate Antonio Gavin and titled The Great Red Dragon; or The Master-Key to Popery, becoming a best-seller that continued to be printed throughout the nineteenth century. A former Spanish priest who fled in disguise to England and eventually settled in Ireland, he preached as a Church of Ireland minister in Gowran, Cork, and Shandon, eventually dying in Ireland 'somewhat forgotten'. ${ }^{42}$ Gavin traded in the most outrageous gossip and stories about the Catholic clergy, including one of the famous tales that purported to expose officials of the Inquisition who filed charges against beautiful women in order to have them arrested and held as a private 'ecclesiastical harem' behind the walls of the Inquisition. This vignette has had such a long shelf life that it was recently used as the basis for the film Goya's Ghosts (2006) which advertised the events depicted in the movie as 'true'. 
In addition to the religious condemnation of the clergy, monks and nuns in particular, there was a sudden uptick in the depiction of Catholic clergy in provincial British newspaper stories that date back to the 1745 uprising to restore the Stuart line to the throne. At this particular time a number of "circulated horror stories about the intentions of Papists in different parts of the kingdom' began to proliferate. ${ }^{43}$ We also know that a variety of anti-Catholic popular publications featuring foolish or lecherous monks were widely available throughout Europe and England since the Reformation, for instance Pierre du Moulin's The Monk's Hood Pull'd Off: or the Capucin Fryar Described (1671), about group flagellation and the overzealous friar who castrated himself, and the ballad 'The Lusty Fryar of Flanders' (1688), based on the saga of Cornelius Adriaensen (1521-81), a Franciscan in Bruges who specialized in whipping his nude female followers. ${ }^{44}$ All of these middling and lower-class texts would have produced in the Protestant imaginary a very real tendency to see Catholics as 'foreign' and dangerous in a traitorous manner, with monks in particular being represented as secretive, sexually deviant, and mysterious.

These examples of anti-Catholic polemic verged close to the pornographic from their inception because a large part of the Protestant case against Catholicism included sexual issues, in particular, clerical celibacy. To the Protestant mind, clerical celibacy was unnatural, perverse, and doomed to fail and, in doing so, to cause incalculable damage to both the clergy and their victims. In A Short History of Monastical Orders we are informed that 'Nuns[,] to conceal from the World their Infamous Practices, made away secretly their Children; and this was the Reason, why at the time of the Reformation, so many Bones of Young Children were found in their Cloisters, and thrown into places where they ease Nature ${ }^{45}$ This accusation surfaces in any number of gothic novels, most strongly in Maria Monk (1836). Other examples 
of this kind include Nunnery Tales Written by a Young Nobleman (1727), a three-volume French novel published in England as Nunnery Tales by the pornographers John and William Dugdale; and John Fairburn's Atrocious Acts of Catholic Priests, who have lately committed the most Horrid and Diabolical Rape and Murders in Ireland and France (1824), and his The Rape and Assassination of Marie Gerin by Mingrat, a French Catholic Priest (1824), the latter two volumes culled from articles in French and Irish newspapers.

\section{II: The Chapbooks}

I think it is no coincidence that Matthew Lewis served one term as a Whig Member of Parliament, while Horace Walpole's father Robert was the first Whig Prime Minister of England. Lewis also was one of the earliest and most vehement practitioners of the antiCatholic gothic, although Ann Radcliffe's three major gothic novels all contain vignettes or 'type scenes' of an anti-Catholic nature: i.e., the suffering nun and the evil abbot in A Sicilian Romance, the convent kidnapping and abbey persecution of Adeline in The Romance of the Forest, and the evil abbess and Inquisition scenes in The Italian. Lewis's The Monk, however, was the mother-lode of anti-Catholic propaganda, and its sub-plots, particularly those featuring Raymond and Agnes and the Bleeding Nun, were mined for decades as the source material for chapbooks, novellas, penny dreadfuls, ballads, operettas, melodramas, and even paper dolls that were sold for children. ${ }^{46}$ The novel's popularity was so immense that it spawned a virtual publication industry, and was the basis of the majority of the imaginative content of chapbooks that concerned the Catholic monk and his nefarious activities. The novel was so sprawling that there were at least three separate tales within it, each of which could be focused on as the content for an entire chapbook. The first and perhaps the most popular excerpt from the novel 
concerned the tale of the 'Bleeding Nun', derived from German sources and adapted by Lewis to supplement the story of Raymond and Agnes, the pregnant nun held captive below the Convent of St. Clare. But, while the emphasis in the Bleeding Nun tale appears to be horror and the fear of the dead walking, the story also relies on the familiar tropes of the profligate nun, the unchaste and undead Sister who continues to seek out male victims for her unsated lust, much like a proto-vampire. For instance, the Preface to one of the chapbook editions of The Monk, The Castle of Lindenberg; or the history of Raymond \& Agnes, a Romance (1799), states the ideological agenda quite clearly:

The subject of the following pages is founded on those remoter days of our ancestors when, blinded by superstitions, they sacrificed their dearest interest to the will of monastic fanatics who, under the pretence of religion, committed the most cruel actions; and with a zeal, deaf to all those tender feelings which distinguished a true Christian, let fall their revenge on all those who were so unfortunate as to deviate from the path they had drawn out for them to pursue. ${ }^{47}$

We do know that Bennett Dugdale had parents in England and that he traveled there frequently to visit family. ${ }^{48}$ When the Copyright Act went into effect on July 2, 1801, the 'Dublin reprinting of current works was virtually stopped and the booksellers had to look to London and Edinburgh for much of their supply' ${ }^{49}$ It is precisely at this point that Dugdale began a collaboration with the London publishing firm of one Thomas Tegg (1776-1846), himself an unscrupulous London publisher who, in fact, had attributed one of his own books, The Biographical Annals of Suicides (1803), to the notorious Irishman George Barrington (c. 1758- 
1804), the 'celebrity convict', pickpocket, and thief who once escaped Ireland dressed as a Catholic priest (shades of Gavin) and was now living as a transported felon in New South Wales. I bring in the 'young genteel Irishman' because he is such a perfect representation of the crosscultural hybridized construction of Irish and English culture existing at this time. ${ }^{50}$ Both historically 'real' and a fantasy construct of the English imagination, this Irishman became famous in England as the 'Prince of Pickpockets', and the supposed author of A Voyage to New South Wales (1795), as well as a variety of other books about spies and suicides (both extremely popular topics in early nineteenth-century British culture). Barrington actually wrote nothing except letters continually asserting his innocence to charges of theft, yet he is identified as the author of a number of books published by any number of British publishers, Tegg being just one of them. ${ }^{51}$ Tegg was as prolific and successful a publisher of reprints, remainders, and cheap reading materials intended for the lower and middling classes in London as Dugdale was in Dublin. In many ways their publishing collaboration made eminent sense, and both of them appear to be nothing if not ruthless in their publication schemes. At one point in his reprinting career, Tegg simply ripped off the conclusion to Milton's Paradise Lost in order for it to fit into its page allocation. ${ }^{52}$

As his contemporary biographer has shown, Barrington could not have been the author of any of the books attributed to him. ${ }^{53}$ His name, notorious and widely-recognized as it was with the lower and middling classes as something of a folk hero, was simply appropriated by the book's publisher Tegg in order to sell books to salvage his struggling publishing house (he was parting ways with Castleman at exactly this time). The full title of the original work is The Biographical annals of suicide, or Horrors of self-murder, whether impelled by love, penury, depravity, melancholy, bigotry, remorse, or jealousy, and it consisted of a series of 23 stories that 
he claimed to have uncovered during his extensive travels. When it was reprinted as a chapbook in 1804 in another Tegg production, The Marvellous Magazine, only four tales were selected, three of which featured detailed descriptions of the evil deeds of Catholic clergy as causing the suicides of young and beautiful people. ${ }^{54}$ The first two tales concern Clementina and Eliza, while the third focuses on a Frenchman who is bankrupted and forced into suicide by a corrupt Abbé who is intent on lavishing money on his mistress. Garvey speculates that Tegg himself, rather than Barrington, was the author of these tales, and this is what is most important, I think, for my argument. ${ }^{55}$

The first tale concerns Clementina Pellegrini, consigned to a convent at the age of six when her Genoan father loses his estate to a kinsman, the Marquis Abruzzo. After many years of unhappiness in the convent, Clementina has finally reached the age where she is to be forced to take her final vows and on her final night of freedom, she meets and falls instantly in love with her cousin Jeronymo Abruzzo, the son of her father's old enemy. He instantly proposes marriage, and then convinces his father that in marrying Clementina, they can right the wrongs the family committed years earlier in seizing Pellegrini's fortune. Abruzzo obtains an immediate release of Clementina from the convent, and they rush there the next morning to perform a surprise wedding rather than the long scheduled vows ceremony. Amid much jubilation, however, the evil and haughty Abbess, descended from an old Genoan aristocratic family, seems perturbed and slighted, perhaps even jealous. Without thinking, Clementina accepts a glass of lemonade from the Abbess' hands and it is not long before she is dead, poisoned by the drink. When the Abbess's family is able to use its wealth and influence to have her released from a prison sentence, the Abbess is attacked during a public procession and stoned to death by the population. And the dramatic dénouement of the tale occurs when Clementina's coffin is carried 
through the streets of Genoa in a procession to the cemetery. As it passes below him, Jeronymo flings himself onto it, 'dashing his brains out and scattering them on the black pall' (p.82), dying instantly, to be buried with his bride in the same tomb.

In the second tale about 'Eliza or the Unhappy Nun', we learn of a young British girl forced into a French convent by her fanatical Catholic father from 'S---d [Sheffield], in the north of England'. Here we are given an anglicized story of Mme. Genlis's 'Cecilia, the Beautiful Nun' or Clementina, a direct and fearful confrontation of the British Protestant imaginary with the religious tyrannies practiced in the Roman Catholic convent (see Figure One):

\section{[INSERT HERE]}

Figure One: Chapbook version of 'George Barrington', Eliza, the Unhappy Nun. London: Thomas Tegg, 1804. Reproduced courtesy of the Sadleir-Black Collection, the University of Virginia Library

There are hints that the Abbess who presides in this convent is not just cruel, but the suggestion is that she is also a lesbian (much like the Abbess in 'Clementina') who jealously wants complete control and dominance over her young charges. Further, we are told that below the convent there are two underground prison cells strewn with the bones of other unlucky nuns, a veritable chamber of horrors.

In this brief tale, all of the familiar tropes are brought out and used to great effect: a 
cultured and cosmopolitan British man is traveling in the south of France during 1791 and he hears a tale about a British woman who had been killed in a convent by a cruel Abbess more than thirty years earlier. As he inquires in the village about the convent and the history of the beautiful but tragic British nun, he learns that the revolutionary troops are preparing to descend on the town, attack the convent, and murder the Abbess, all of whom agree has been a tyrant and oppressor for decades. Taken on a tour of the ruined and burned convent, the nameless narrator finds a handwritten testament composed by Sister Eliza and we have a first-person narration of how one British woman found herself in a convent's underground dungeon, where she was 'buried alive', starved, and eventually committed suicide by slitting her wrist with a razor, as shown in the illustration above (p.87).

The action of the inset narrative takes place in 1759, when the fifteen year old Eliza $\mathrm{H}$ is forced by her cruel father to take vows as a nun in a small convent outside of Nice. Her only friend is a Sister Madeleine who has been forced into the convent as well, this time by a stepmother who did not want her to marry a distant relative. When Eliza appears as a nun in her first religious procession on the feast day of St. Philip, she is spotted by Charles de R..., a handsome young man who falls instantly in love with her and proposes marriage via letters smuggled into the convent. Through her network of spies, the jealous Abbess discovers these letters and sentences Sister Eliza to banishment below the convent, where she is slowly starved to death. Her final act is to leave a written testament, to be given to her father on her death, before she slits her wrists and bleeds to death. This nun's tale, which in various versions we find throughout gothic novels like The Monk, The Abbess, and Legends of a Nunnery, stands as a curious hybrid: a denunciation of the worst abuses of the French convent system, justifiably destroyed by the French Revolution. And yet the British Protestant imaginary that reveled in these tales was not 
politically radical, nor was it in sympathy with the principles or the spread of the French revolutionary ideals onto British soil. This confused ideological agenda accounts, I think, for the critical splits in trying to decipher the use that the gothic makes of Catholic religious tropes.

Four of the nineteen gothic chapbooks that Dugdale and Tegg published are anonymous and clearly anti-Catholic productions: Amalgro \& Claude; or the Monastic Murder (1803), Father Innocent (1803), The Secret Tribunal; or, The Court of Wincelaus (1803), and Phantasmagoria, or the Development of Magical Deception (1803), and most of them conform to the pattern described by Loeber and Loeber in that they 'were illustrated with a frontispiece representing a terrifying or crucial scene from the narrative, ${ }^{56}$ while they promulgate a 'discourse which associates monstrosity, Catholicism, and sublimity [for] the Irish Anglicans attempting to come to terms with the "enemy" in their midst' ${ }^{57}$ They are all, in fact, virtual miniature plagiarisms of their source texts, either The Monk for Amalgro \& Claude and Father Innocent, or Friedrich Schiller's The Ghost-Seer (1789; trans English 1795) for Phantasmagoria, or Christiane Naubert's Hermann von Unna (1788; trans English 1794), a novel purporting to expose the workings of 'secret tribunals' at the corrupt aristocratic court of the Emperors Winceslaus and Sigismond in Westphalia, for The Secret Tribunal.

There is no question that Hermann was extremely popular in Britain and has long been recognized as an important influence on Radcliffe's depiction of the Inquisition in The Italian (1797). In addition, James Boaden virtually plagiarized the work as his gothic drama The Secret Tribunal (Covent Garden, 1795), while a redaction of the novel appeared as an 1803 chapbook (See Figure Two). Felicia Hemans later adapted the legend as the basis for her long narrative poem A Tale of the Secret Tribunal (comp. early 1820s; publ. 1845), citing Madame de Staël's De l'Allemagne (1813) as her source. Walter Scott also drafted a Tribunal play himself, 'The 
House of Aspen', based on Veit Weber's Sagen der Vorzeit in 1799.

Friedrich von Schiller's Der Geisterseher, translated into English as The Ghost Seer or the Apparitionist, was the major Germanic source for both The Monk and Melmoth the Wanderer, as well as a number of German necromancer novels, most famously K. F. Kahlert's Der Geisterbanner, 1790 (The Necromancer, trans Peter Teuthold, 1794) and its chapbook redaction Phantasmagoria. The Ghost-Seer is a scathing portrait of the real-life Masonic charlatan, Count Cagliostro, a Sicilian who performed across Europe in the late 1780s as a fortune teller and séance leader and was eventually executed by the Inquisition in Rome in 1795 . Rumored to be a member of the Illuminati, a revolutionary group of Freemasons who used a number of sensory tricks (magic lanterns, exploding powders) to gain power over their gullible victims, the Freemasons' aim was to assume control over the property of their bamboozled adherents (usually convents of easily duped nuns). By extension, fear of the Illuminati was based on the belief that they could use these same techniques on powerful 'Princes' in order to gain power over nation-states. Schiller's short mystery was also supposedly modeled on yet another contemporary historical figure, the third son in line to the dukedom of Würtemberg, whose family was Protestant but who was himself rumored to be considering the idea of converting to Catholicism. The Ghost-Seer tells the tale of a young German prince driven by a mysterious monk first to religious skepticism, then to libertinism, and finally to murder in the religiously paranoid atmosphere of Venice. Raised in a strict Protestant society, the Prince's naturally good feelings and impulses are corrupted so thoroughly that he easily falls prey to the superstitious mysteries and displays that the mysterious Armenian monk offers to him. The Ghost-Seer is almost a textbook study of the 'explained supernatural', except that all of the supernatural powers of the so-called 'Incomprehensible' Armenian monk are finally not 
explained fully, nor is the work finished. Influenced by the Schwabian pietism of his youth, Schiller focused on a depiction of God as a punishing force and his Ghost-Seer returns repeatedly to exploring the unfortunate connection between freethinking and damnation, skepticism and credulity. The use that these two chapbooks make of the themes of political

revolution, upheaval, and invasion would have been particularly anxiety producing in an AngloIrish reading population at this time. With the failure of the 1798 uprising, the French invasion at County Mayo and their defeat in September, and then the attempted invasion with the involvement of Wolf Tone later that same year, the Anglo-Irish Protestant majority would still have been anxious and would have feared yet another imminent invasion, particularly after Bonaparte's coronation in December 1804.

\section{[INSERT HERE]}

Figure Two: Frontispiece to Anon., The Secret Tribunal; or, The Court of Wincelaus. London: Thomas Tegg, 1803. Reproduced courtesy of the Sadleir-Black Collection, University of Virginia Library.

The two gothic chapbooks based on The Monk-Amalgro \& Claude and Father Innocent (see Figure Three) — are both hyperbolic texts full of events that feature elaborate costuming, excess, and the sort of displays of clerical corruption and wealth that the Methodist mentality would have found deeply disturbing and offensive. Amalgro \& Claude is 40 pages and focuses on retelling the banditti inset tale in conjunction with the bleeding nun narrative, while Father 
Innocent is a 72-page novella concerned with the Ambrosio and Matilda story. As Cooney has shown, the Irish Methodists recruited their membership from the Church of Ireland and nonconformists, people who were artisans and 'upwardly aspiring commercial classes', particularly characterized by their industry, thrift, and hard work. ${ }^{58}$ Such a description accurately characterizes Bennett Dugdale, who converted to Methodism after hearing John Wesley preach in Dublin during his fourteenth visit to the city in 1773. Before long, Dugdale was a 'prominent member' of the Primitive Wesleyan Methodist Society, frequently preaching at the Methodist chapel and spearheading the drive to raise funds in order to build a new and large assembly hall for the Methodists. ${ }^{59}$ As a publisher we know that he was particularly interested in producing anti-slavery tracts, Methodist hymnals, and religious pamphlets, in addition to these five antiCatholic gothic chapbooks. ${ }^{60}$ In short, he was not simply a 'pious publisher' as Cooney states, or just an ambitious Dublin-based collaborator of Thomas Tegg, as Loeber and Loeber suggest. He was also a Methodist propagandist who used his publishing firm to produce the sort of works that he and his associates thought would best advance the cause of Methodism in Ireland. To extrapolate from that conclusion, we might very well conclude that many of the publishing houses in Dublin during this period had unspoken but very clear political and religious agendas that can be discerned by a careful reading of their publication lists.

\section{[INSERT HERE]}


Figure Three: Frontispiece to Anon., Father Innocent. London: Thomas Tegg, 1803. Reproduced courtesy of the Sadleir-Black Collection, University of Virginia Library.

\section{NOTES}

${ }^{1}$ Elizabeth Bonhôte (1773) The Rambles of Mr. Frankly, Published by His Sister, 2 vols. (Dublin: Messrs. Sleater, Lynch, Williams, Potts, Chamberlaine), I: 67.

${ }^{2}$ James Watt (1999) Contesting the Gothic: Fiction, Genre and Cultural Conflict, 1764-1832 (Cambridge: Cambridge University Press), p. 47.

${ }^{3}$ Mary Muriel Tarr (1946) Catholicism in Gothic Fiction (Washington, D.C.: Catholic University Press), p. 64; see also Christina Morin (2011) 'Forgotten Fiction: Reconsidering the Gothic Novel in Eighteenth-Century Ireland', Irish University Review 41.1, 80-94.

${ }^{4}$ Rolf and Magda Loeber (2003) 'The Publication of Irish Novels and Novelettes: A Footnote on Irish Gothic Fiction', Cardiff Corvey: Reading the Romantic Text, 10, n.p. (p. 26). Available online from www.cardiff.ac.uk/encap/journals/corvey/articles/cc10_n02.pdf. Accessed 1 May 2012.

${ }^{5}$ Cooney notes that 'in 1787 there were 53 printers in the city [of Dublin]. Bookbinders were rather fewer, but of booksellers there were in 1790 a total of $65 . .$. In these circumstances, the Dublin book trade flourished. These halcyon days, however, were coming to an end' with the passage of the Act of Union; Dudley Levistone Cooney (2002) 'Irish Methodism', in Christianity in Ireland, ed. Brendan Bradshaw and Daire Keogh (Dublin: Columbia Press), pp.144-54 (p.78). Pollard notes a steep decline in publishing output in Dublin after 1793, but notes that there was 
an almost double rise in importing books from England during the 1790s; Mary Pollard (1989) Dublin's Trade in Books (Oxford: Clarendon Press), pp.154-55.

${ }^{6}$ Charles Benson (2011) 'The Dublin Book Trade', in The Irish Book in English 1800-1891, ed. James H. Murphy (Oxford: Oxford University Press), pp.27-46 (p.30).

${ }^{7}$ For further historical context to this issue, see James Kelly, Prelude to Union: Anglo-Irish Politics in the 1780s. Cork: Cork UP, 1992; Kevin Whelan, Fellowship of Freedom: The United Irishmen and 1798. Cork: Cork UP, 1998; and Thomas Bartlett, The Fall and Rise of the Irish Nation: The Catholic Question, 1690-1830. Dublin: Gill and Macmillan, 1992.

${ }^{8}$ Benson, 'The Dublin Book Trade', p.32.

${ }^{9}$ Quoted in Benson, 'The Dublin Book Trade', p.35.

${ }^{10}$ Foster has noted that major Irish gothic novelists like Maturin, Le Fanu, and Stoker all shared 'occult preoccupations [that] surely mirror a sense of displacement, a loss of social and psychological integration, and an escapism motivated by the threat of a takeover by the Catholic middle classes'; Roy Foster (1995) Paddy and Mr Punch: Connections in Irish and English History (London: Penguin), p.220.

${ }^{11}$ Fenning has traced in detail the conditions of Catholic bishops and laity in Ireland during the eighteenth century, particularly with regard to the passage of a series of bills that gradually restored voting and property rights to Catholics. As he observes, in 1707 there was only one Catholic bishop in Dublin and he was in prison; Hugh Fenning, OP (2002) 'A Time of Reform: From the "Penal Laws" to the Birth of Modern Nationalism, 1691-1800', in Christianity in Ireland, pp.134-43 (p.135). When The History of Andrew Dunn, an Irish Catholic, a religious 
fiction about the conversion of a man from Protestantism to Catholicism was published anonymously in 1814 by the Religious Tract Society, it was published in London. See Rolf and Magda Loeber (2006) A Guide to Irish Fiction 1650-1900 (Dublin: Four Courts Press), p.688 for bibliographical details.

${ }^{12}$ My forthcoming book from the University of Wales Press, The Gothic Ideology: Religious Hysteria and Anti-Catholicism in British Popular Fiction, 1780-1880, examines in much greater depth the complex and convoluted sources of anti-Catholicism in British gothic texts.

${ }^{13}$ Rolf and Magda Loeber (1998), 'John Connor: A Maverick Cork Publisher of Literature', $18^{\text {th }}$ $19^{\text {th }}$ Century Irish Fiction Newsletter 5, n.p.

${ }^{14}$ See Irene Bostrom (1963) 'The Novel and Catholic Emancipation', Studies in Romanticism 2, 155-76; Victor Sage (1988) Horror Fiction in the Protestant Tradition (London: Macmillan); Susan Griffin (2004) Anti-Catholicism and Nineteenth-Century Fiction (Cambridge: Cambridge University Press); Diane Long Hoeveler (2012) 'Anti-Catholicism and the Gothic Imaginary: The Historical and Literary Contexts', Religion in the Age of Enlightenment 3, 1-31; Diane Long Hoeveler (2013) 'Demonizing the Catholic Other: Religion and the Secularization Process in Gothic Literature', in Transnational Gothic: Literary and Social Exchanges in the Long Nineteenth Century, ed. Monika Ebert and Bridget Marshall (Aldershot: Ashgate), pp. 83-96. ${ }^{15}$ Loeber and Loeber, 'The Publication of Irish Novels and Novelettes', p.29.

${ }^{16}$ In 1810 Walter Scott famously claimed that the gothic was an 'unthinking mass production [done by] hack writers ... writing solely for gain'; quoted in Michael Gamer (2002) 'Gothic Fictions and Romantic Writing in Britain', in The Cambridge Companion to Gothic Fiction, ed. Jerrold Hogle (Cambridge: Cambridge University Press), p.91. 
${ }^{17}$ What we know about Dugdale's personal and religious history and his professional activities as a publisher has been summarized in the biographical articles by Cooney and Pollard; see Cooney, 'Irish Methodism' and Mary Pollard (2000) A Dictionary of Members of the Dublin Book Trade, 1550-1800 (Cambridge: Bibliographical Society), pp.172-3.

${ }^{18}$ Loeber and Loeber, 'The Publication of Irish Novels and Novelettes', p.26.

${ }^{19}$ Cooney, 'Irish Methodism', pp.53, 98.

${ }^{20}$ Loeber and Loeber ('The Publication of Irish Novels and Novelettes', p.20) comment on the use that Dublin publishers made of works pirated from London, as well as the opposite occurrence, the pirating of an Irish author's work by London publishers. Given the revisions in copyright law that occurred throughout the eighteenth century, copyright infringement was not rigorously enforced, although publishers themselves tended to work to ostracize a particularly egregious offender. Haywood and Groom both provide detailed overviews of the culture of literary piracy and the issue of spurious authorship of books during this period; see Ian Haywood (1987) Faking It: Art and the Politics of Forgery (Brighton: Harvester), esp. pp.21-70, and Nick Groom (2002) The Forger's Shadow: How Forgery Changed the Course of Literature (London: Picador).

${ }^{21}$ Loeber and Loeber, 'The Publication of Irish Novels and Novelettes', p.22.

${ }^{22}$ See Maureen Wall (2001) 'The Age of the Penal Laws', in The Course of Irish History, ed. T.W. Moody and F.X. Martin (Cork: Mercier Press), pp.176-89.

${ }^{23}$ Albert D. Pionke (2004) Plots of Opportunity: Representing Conspiracy in Victorian England (Columbus: Ohio State University Press), p.54. 
${ }^{24}$ Colin Haydon (1993) Anti-Catholicism in Eighteenth-Century England, c. 1714-80: A

Political and Social Study (Manchester: Manchester University Press), p.42.

${ }^{25}$ Linda Colley (1992; 2009) Britons: Forging the Nation 1707-1837 (New Haven, CT: Yale University Press), p.23.

${ }^{26}$ Nicholas Rogers (2004) 'Popular Culture', in The Enlightenment World, ed. Martin

Fitzpatrick, Peter Jones, Christa Knellwolf, and Iain McCalman (London: Routledge), pp.401-17 (p.408).

27 The association of Catholicism with witchcraft, black magic, and diabolical sorcery goes back to the Reformation period (Spencer's Duessa in The Faerie Queene, Milton's Dalila in Samson Agonistes). See Deborah Willis (1995) Malevolent Nurture: Witch-Hunting and Maternal Power in Early Modern England (Ithaca, NY: Cornell University Press) for further examples of this association.

${ }^{28}$ Haydon, 'Anti-Catholicism', pp.41, 58.

${ }^{29}$ Haydon, 'Anti-Catholicism', pp.42, iv.

${ }^{30}$ Statutes of the Realm: volume 7: 1695-1701 (1820), pp. 586-87. URL: http://www.britishhistory.ac.uk/report.asp?compid=46963. Accessed August 15, 2013.

${ }^{31}$ Haydon, 'Anti-Catholicism', p. 68.

${ }^{32}$ Haydon, 'Anti-Catholicism', p. 60.

${ }^{33}$ Haydon, 'Anti-Catholicism', p. 60.

${ }^{34}$ The print is available in the British Museum, Department of Prints and Drawings, 5,685; qtd. Haydon, ‘Anti-Catholicism', p. 65.

${ }^{35}$ George Rudé (1971) Paris and London in the Eighteenth Century: Studies in Popular Protest (New York: Viking), p. 139. 
${ }^{36}$ Colley, Britons, p.332.

37 The most extensive discussion of the class motivations of the people who participated in the Gordon Riots can be found in Rudé, Paris and London, pp. 268-92. While the initial participants of the demonstration appear to have been tradesmen, the ranks soon swelled with weavers from Spitalfields and an 'inferior set' shouting 'No Popery!' The first building to be attacked was the private chapel of the Sardinian embassy and the next was the chapel attached to the Bavarian embassy. Both chapels were known to have been frequented by aristocratic British Catholics; Rudé, Paris and London, p.271.

${ }^{38}$ Colley, Britons, p.337.

${ }^{39}$ Huxley notes that the gulf between official Catholic teaching and practice by individual ecclesiastics was 'enormous' during the early modern period: 'it is difficult to find any medieval or Renaissance writer who does not take it for granted that, from highest prelate to humblest friar, the majority of clergymen are thoroughly disreputable. Ecclesiastical corruption begot the Reformation, and in its turn the Reformation produced the Counter Reformation'; Aldous Huxley (1952) The Devils of Loudon (London: Chatto and Windus), p. 6. For a survey of dozens of historical incidents involving eighteenth-century Spanish priests who had affairs and illegitimate children with their female confessors, see Stephen Haliczer (1996) Sexuality in the Confessional, A Sacrament Profaned (Oxford: Oxford University Press). Several of these affairs, in which both participants were denounced to the Inquisition and forced to stand trial, read as the historical source material for any number of gothic novels by Ireland and Montague. ${ }^{40}$ Karl Toepfer (1991) in Theatre, Aristocracy and Pornocracy: The Orgy Calculus. New York: PAJ Publications, makes the same sort of distinction in his study of ancien régime 
Enlightenment theater, contrasting the open and democratic aspect of carnivalesque excess and the secret, closed, and exclusive quality of libertine orgies practiced by the aristocracy (10-13).

${ }^{41}$ Robert Darnton (1982) The Forbidden Best-Sellers of Pre-Revolutionary France (London: HarperCollins), p.107.

${ }^{42}$ Henry Spencer Ashbee (1879; 1962) Centuria Librorum Absconditorum, vol. 2 (London), p.121.

${ }^{43}$ Haydon, 'Anti-Catholicism', p.38.

${ }^{44}$ Roger Thompson (1979) Unfit for Modest Ears: A Study of Pornographic, Obscene and Bawdy Works Written or Published in England in the Second Half of the Seventeenth Century (Totowa, N.J.: Rowman and Littlefield), pp.147, 142.

${ }^{45}$ A short history of monastical orders in which the primitive institution of monks, their tempers, habits, rules, and the condition they are in at present, are treated of / by Gabriel d'Emillianne [pseudonym of Gavin, Antonio, fl. 1726]. London: Printed by S. Roycroft, for W. Bentley, 1693, pp. 133-34.

${ }^{46}$ Diane Long Hoeveler (2010) 'More Gothic Gold: The Sadleir-Black Chapbook Collection at the University of Virginia Library', Papers on Language \& Literature 46, 164-91.

${ }^{47}$ The Castle of Lindenberg; or the history of Raymond \& Agnes, a Romance. London: Fisher, 1799, p. 3.

${ }^{48}$ Cooney, 'Irish Methodism', p.87.

${ }^{49}$ Benson, 'The Dublin Book Trade', p.40.

${ }^{50}$ Nathan Garvey (2008) The Celebrated George Barrington: A Spurious Author, the Book Trade, and Botany Bay (Potts Point, Australia: Hordern House), p.2. 
${ }^{51}$ In addition to Garvey on the contested biography of Barrington, see Sheila Box (2001) The Real George Barrington? The Adventures of a Notorious London Pickpocket, later Head Constable of the Infant Colony of New South Wales (Melbourne: Australian Scholarly Publishing), pp.11-25. Both Frank and Mulvey-Roberts mistakenly identity Barrington as the author of Eliza, The Unhappy Nun; Frederick S. Frank (1987) The First Gothics: A Critical Guide to the English Gothic Novel (New York: Garland), p.22, and Marie Mulvey-Roberts, 'Biographies of Gothic Novelists'. Available online from http://www.ampltd.co.uk/digital_guides/gothic_fiction/biographies.aspx. Accessed 1 May 2012. Summers describes Tegg's production of chapbooks, stating 'there was no busier house in this particular trade than that of Thomas Tegg, No. 3 Cheapside, and it may be remarked that his bluebooks are far better printed than the majority of these miniature romances'; Montague Summers (1938) The Gothic Quest: A History of the Gothic Novel (London: Fortune), p. 83. 52 James J. Barnes and Patience Barnes (2000) 'Reassessing the Reputation of Thomas Tegg, London Publisher, 1776-1846', Book History 3, 45-60 (p.48). Tegg's publishing career is analyzed in a good deal of detail in Barnes and Barnes, who note that he was known in London as 'the broom that swept the booksellers' warehouses', a reference to the fact that he successfully exploited the reprint and remainder trade. At his death his obituary identified him as the single most prolific publisher in London; Barnes and Barnes, 'Reassessing the Reputation', p.45. ${ }^{53}$ Garvey, The Celebrated George Barrington, p.154.

54 "Barrington, George" [Thomas Tegg?]. Eliza, or the Unhappy Nun, exemplifying the unlimited tyranny exercised by the abbots and abbesses over the ill-fated victims of their malice 
in the gloomy recesses of a convent. Including the Adventures of Clementina... London: Tegg, 1803. Rpt. Marvellous Magazine (1804) III: 83-94.

${ }^{55}$ Garvey, The Celebrated George Barrington, p.159.

${ }^{56}$ Loeber and Loeber, 'The Publication of Irish Novels and Novelettes', p.18.

57 Jarlath Killeen (2005) Gothic Ireland: Horror and the Irish Anglican Imagination in the Long Eighteenth Century (Dublin: Four Courts Press), p.131.

${ }^{58}$ Cooney, 'Irish Methodism', p.146.

${ }^{59}$ Cooney, 'Irish Methodism', p.81.

${ }^{60}$ Pollard, A Dictionary of Members, pp.172-3. 